\title{
Jerzy Węcławski
}

Maria Curie-Skłodowska University

e-mail: jerzy.weclawski@poczta.umcs.lublin.pl

\section{Helmut Pernsteiner}

Johannes Kepler University Lintz

e-mail: Helmut.Pernsteiner@jku.at

\section{FACTORS OF INFLUENCE ON RELATIONSHIP BANKING OF POLISH FIRMS}

\section{CZYNNIKI KSZTAŁTUJĄCE BANKOWOŚĆ RELACYJNA $W$ ODNIESIENIU DO POLSKICH PRZEDSIECBIORSTW}

\section{DOI: $10.15611 /$ pn.2017.482.21}

JEL Classification: G21, G30

Summary: One factor in the field of relationships to banks is the so-called relationship banking, which is a well-known practice in the bank oriented economies in Europe. Relationship banking means a long run relationship between one or a small number of banks to firms, especially in lending, so the terminus is in this field relationship lending. On the basis of a huge telephonequestionnaire in Poland concerning financial management we have tried to answer some research questions in the field of relationship banking in detail in order to bring light into this somewhat dark area of relationships between banks and firms. The main aspect of relationship banking is the duration of this relationship. Using empirical methodology, we analyse this relationship on the basis of the length of time as well as aspects such as the age of the firm, the number of bank relationships, the industry, the influence of strategies and the access to credits.

Keywords: banking, relationship banking, relationship lending.

Streszczenie: Jedną z form współpracy banków z przedsiębiorstwami jest bankowość relacyjna, stosowana zwłaszcza w zorientowanych bankowo systemach finansowych krajów europejskich. Bankowość relacyjna polega na długoterminowej współpracy przedsiebiorstwa z jednym bądź niewielką liczbą banków, w szczególności w zakresie kredytowania, co jest określane pojęciem relacji kredytowych. W opracowaniu przedstawione zostały wyniki badań ankietowych dotyczących zarządzania finansami w polskich przedsiębiorstwach odnoszące się do kilku problemów z zakresu bankowości relacyjnej. Podstawowym wyróżnikiem bankowości relacyjnej jest czas trwania współpracy. W oparciu o metody statystyczne przeprowadzono analizę tej współpracy na podstawie długości jej trwania, jak również aspektów takich, jak: wiek firmy, liczba relacji bankowych, rodzaj działalności, stosowane strategie i dostęp do kredytów.

Słowa kluczowe: bankowość, bankowość relacyjna, relacje kredytowe. 


\section{Introduction}

In the field of business research, the relationships of firms to banks normally are not in the central focus.

From the point of view of the enterprise two lines are important: on the one hand, the firm chooses from some offers of the bank products (e. g. loans) and finds the best - and this very often means the cheapest offer. In this area, the enterprise likes to have contacts at many banks so it is sure to get some interesting and attractive offers. The relationships with the banks are very professional with low personal contact levels; there no longer is any binding between the two institutions. This is typical for the Anglo-Saxon world, where public capital markets are well developed.

On the other hand - mainly in the countries in Continental Europe, the so-called 'bank economies' - there are strong relationships between one, two or even more banks to a firm. The term for this long run relationship is relationship banking [Iturralde et al. 2010, p. 276]. If you compare this system, e.g. in the case of lending [Berger, Udell 2002], with the abovementioned, you will find a lower level of competition, because it is very clear that the competition is mainly between two or even three banks. If there is strong relationship banking - this means the contacts are only to one bank - there is even no competition [Pernsteiner, Węcławski 2016, p. 46]. So, the firm may have the fear to pay too much, for example for a loan [Degryse, Van Cayseele 2000, p. 107] or hope for a cheaper loan because of being an important and long run client of the bank [Carletti 2004, p. 81]. But even when the enterprise pays 'too much', it sees this long relationship as a partnership and, therefore, as a kind of insurance for the time of the crisis [Iturralde et al. 2010, p. 290; Sauter 2015, p. 30].

In such a dark period, the firm will need additional money to realize the restructuring plan to come to a better future. At such time, it is very difficult to earn money for such a plan: the (old) shareholders are mainly not able to give additional money, new shareholders cannot be found because of the bad economic situation, new banks see their engagement as too risky, so the (old) bank is the only one which is maybe willing to make a further engagement. Now the relationship banking-process is at work: as a result of the long-time relationship, the so-called 'mother bank' has gathered huge information about the enterprise and can decide very precisely. The former engagement of the bank was very high, so the loss in the case of default of the firm is often very high; as a consequence, there is a high interest of the bank to bring the firm out of the crisis, maybe with fresh money.

This article deals with relationship banking of Polish firms. Poland, as one of the largest Eastern-European countries, achieved many years of high growth rates after the transformation to a market economy since the early 1990's. The financial system is a bank-oriented one - as a typical Continental European country - and banks are strongly engaged in corporate finance. The banks have a high level of competitiveness, but they are in favour of relationship banking. 
We bring light into this somewhat dark area of relationship banking of Polish firms based on a huge telephone-questionnaire of 758 Polish firms, which are not SMEs. More specifically, our basis point is the duration of the relationship between the bank and the firm.

Using empirical methodology, we analyse this relationship on the basis of the length of time [Berger, Udell 1995, p. 352; Iturralde et al. 2010, p. 276]. The analysis is oriented on two groups of factors: variables characterizing the firm, such as the age of the firm, the industry and the influence of corporate strategies; and variables characterizing the relationship between banks and firms, including the number of bank relationships and the access to loans.

There are nearly no research results available for these aspects for European firms, and specifically for Polish firms [Tymoczko, 2012]. With its outcomes, the presentation shall set some stones for this research mosaic in the field of finance and banking.

The authors are very grateful to the financial aid given from the Polish National Science Centre (NCN Project No. 2012/07/B/HS4/00455, "Corporate governance ownership structure and other financial issues of family business in Poland and Austria - a comparative analysis").

\section{Literature review}

Relationship banking, as mentioned - the dominant relationship structure between banks and firms in Poland, is primarily focused to relationship lending, which means realizing the need of the enterprises for liquidity via banks for some years. Berger and Udell said that "the process of relationship lending is not well understood" [2002, p. F 47].

From the point of view of the bank, the orientation is clear: it wants the money from their loan back with interest along the fixed timeline, or in other words, it wants to reduce the risk to zero. The main problem in this case is the information asymmetry between the CFOs of the firms and the loan specialists in the banks [Berger, Udell 1995]. For many centuries, banks have been able to deal with these problems and they are experts in using collateral to reduce the risk and covenants to earn more information about the enterprise. This means that besides the collateral, the gathering and analysing of information must be in the focus of the banks. Relationship lending is a main column of gathering such information [Elyasiani, Goldberg 2004], especially of the long time-line of information and the personal contacts established over the years, which lead to a better estimation of the risk related to the firm [von Rheinbaben, Ruckes 2004]. The 'soft' information about the firm, the owners and their relationships, and about the local community are very important (more for smaller firms) - and the loan officer typically has this information [Berger, Udell 2002]. 
Relationship lending has further pros for the banks: The long (personal) contacts may reduce the probability that other banks will enter this relationship with aggressive conditions and, therefore, may improve the ability of the bank to come to signing the credit contract with good conditions for the bank (the firm may pay 'too much'). Important engagement as the lender and personal contacts with the firm both give the chance for more influence in important decisions of the enterprise [Elsas 2005]: on the one hand, with the conditions in the contracts like covenants, and on the other hand, with an advisory position, because of the personal contacts; the latter is more important for small firms. Another positive aspect for the bank is to sell a future loan [Bharath et al. 2007] and the so-called 'cross selling' that means a better ability to sell other non-loan products and services, such as asset management, deposits, insurance, etc. This situation brings about a decreasing interest rate on the loan [Degryse, Van Cayseele 2000]. In a family firm, the contact to the owners may be important for the bank to offer personal loans, personal insurance and private banking products [Sauter 2015]. In general, for small banks the advantages in processing credit information is very important to preserve their niche [Elyasiani, Goldberg 2004].

As abovementioned relationship banking, and especially relationship lending, lead to an "insurance against critical liquidity problems in a crisis or near-crisis; the firm is looking for an additional loan. Another advantage for the firm lies in the hope to achieve better price conditions for all bank products because that bank will see the firm as an important client" [Pernsteiner, Węcławski 2016, p. 47].

There is nearly no research for Poland in this field, especially for non-listed firms. It is even not possible to get some data from public information or data banks. Therefore, we use the methodology of a questionnaire.

\section{Hypotheses}

The main aspect of relationship banking is the duration of this relationship [Iturralde et al. 2010, p. 275]. Therefore, we analyse some relations on the basis of the duration of relationship banking. We argue that some characteristics have large influence to specifications of the firm, such as the age of the firm, the industry and the strategies and goals of the enterprise. The length of the relationship banking is influenced by the number of banks and the number of contacts between the two partners, the access to loans and the level of contentment with the loans in general.

So, we are able to formulate our hypotheses:

$\mathrm{H}$ 1: The length of relationship banking is higher with older firms [Iturralde et al. 2010, p. 290; von Rheinbaben, Ruckes 2004, p. 1611].

$\mathrm{H} 2$ : The length of relationship banking depends on the number of banks and the amount of contacts between banks and firms.

H 3: Relationship banking is more important in the sector of trade/services than in manufacturing firms. 
$\mathrm{H}$ 4: The length of relationship banking depends on the strategies and goals of the firm.

H 5: The length of relationship banking is higher by a good access to loans.

H 6: The length of relationship banking is higher when the contentment with loans is higher.

\section{Data and descriptive analysis}

The data for this project was collected as part of the authors' research. The research was carried out in the second and third quarter of 2014 on a random sample of 758 enterprises in Poland, each of which employs more than 49 persons. The questionnaire - based interviews were carried out using CATI and CAWI techniques.

Most of the enterprises are in the manufacturing sector (57.1\%), the rest are firms acting in the trade and services sector. $45 \%$ of the firms earn the majority of their turnover in the national scale, $35 \%$ in their local Polish voivodeship and only $20 \%$ have foreign activities. The average age of the firms in the data set is 21 years. Only $8 \%$ of the firms are younger than ten years, $42 \%$ have been active between ten and twenty years and $50 \%$ are older than twenty years.

The firms in our data set show a clear hierarchy of goals. For $94 \%$ of the enterprises an important goal is to realize the long-run going concern of the firm, for $77 \%$ it is important to minimize the enterprise risk; $75 \%$ of the enterprises say that independence is very important and they would like to be independent in their activities in the future, too. For nearly $72 \%$ of the firms it is important to realize a high growth rate and for $69 \%$ it is important to improve the long-term value, which is consistent with the management paradigm of shareholder value management and interestingly - only $41 \%$ are short-term oriented in maximizing profits.

Collaboration with banks is another field of interest. $18 \%$ informs that they are working constantly with only one bank, $40 \%$ with two banks, $25 \%$ with three banks and the rest with more banks. Most of the enterprises are dealing for a long time with their most important bank, in detail - nearly $16 \%$ more than twenty years; $40 \%$ between eleven and twenty years and the rest are acting in a shorter period. In her research for Germany and family firms, Sauter [2015, p. 30] found that the average duration of relationships to the main bank is 32 years. We asked further about the number of contacts to the most important bank; $10 \%$ say that their personal contacts with the bank are very frequent, for $71 \%$ they are quite frequent and for $19 \%$ frequent. Interestingly, there is no firm which tell us that the personal contacts are rare. We have to say that this answer is an answer of feeling or behaviour, it can be interpreted that from the point of view of the firms this is too often or that they are happy they are in close contacts.

For the external financing activities of the firms, the bank loans are really important. $73 \%$ of the firms are using short-term loans, $47 \%$ long-term loans. $46 \%$ of the short-term debtors are very satisfied and the same percentage of the firms using 
long-term loans are very satisfied with this instrument, too. An interesting question in the past crisis period is the access to bank credits. $22 \%$ of the firms say that the access to loans is very easy and $47 \%$ say that the access is easy. Only for $5 \%$ of the firms the impression is 'difficult' and nearly $2 \%$ said 'very difficult'.

\section{Econometric Model}

For verifying the hypotheses, we use a linear regression model. The dependent variable is the duration of the relationship banking, the explanatory variables are characterising the firms and the relationship to banks. We use some control variables, too. As control variables, we define turnover 2013, assets 2013 and the number of employees 2013 (X1-X3).

The 14 explanatory variables (X4-17) are:

X4: Age of the firm in years;

X5: Number of banks collaborating with the firm;

X6: Intensity of contacts with the most important bank (an ordinal scale: 1 - very often, 5 - very rare);

X7: Number of banks collaborating with the firm over a long time;

X8: Manufacturing firms (1), others (0);

$X$ 9: Importance of the goal 'long term growth of value' (an ordinal scale: 1 - very low, 5 - very high);

X10: Importance of the goal 'short term maximizing of profits' (as above);

X11: Importance of the goal 'independence of the firm' (as above);

$\mathrm{X} 12$ : Importance of the goal 'high growth rate' (as above);

$\mathrm{X} 13$ : Importance of the goal 'long run going concern' (as above);

X14: Importance of the goal 'minimizing the enterprise risk' (as above);

X15: Access to bank loans (an ordinal scale: 1 - very difficult, 5 - very easy);

X16: Contentment with short-term bank loans (an ordinal scale: 1 -very dissatisfied, 5 - very satisfied);

X17: Contentment with long-term bank loans (as above).

The analysis was realized by SPSS. The estimation for Model(1) which includes all variables and for the other three Models which encompass separated variables $(2,3,4)$ show similar results (Table 1$)$. The correlations among the different variables are shown in Table 2. 
Table 1. Results of estimations of model and significance levels

\begin{tabular}{|c|c|c|c|c|c|c|c|c|c|c|c|c|c|c|c|c|}
\hline \multirow[b]{2}{*}{ Variable } & \multicolumn{4}{|c|}{ Model 1} & \multicolumn{4}{|c|}{ Model 2} & \multicolumn{4}{|c|}{ Model 3} & \multicolumn{4}{|c|}{ Model 4} \\
\hline & B & $\begin{array}{l}\text { Std. } \\
\text { Error }\end{array}$ & $\mathrm{t}$ & Sig. & B & $\begin{array}{l}\text { Std. } \\
\text { Error }\end{array}$ & $\mathrm{t}$ & Sig. & B & $\begin{array}{l}\text { Std. } \\
\text { Error }\end{array}$ & $\mathrm{t}$ & Sig. & B & $\begin{array}{l}\text { Std. } \\
\text { Error }\end{array}$ & $\mathrm{t}$ & Sig. \\
\hline Constant & 3.549 & 6.267 & .566 & .572 & 4.434 & 5.658 & .784 & .434 & 5.792 & 5.675 & 1.021 & .308 & 5.397 & 5.074 & 1.063 & .288 \\
\hline $\mathrm{X} 1$ & 1.077 & 1.248 & .863 & .389 & 0.064 & 0.822 & .077 & .938 & & & & & & & & \\
\hline $\mathrm{X} 2$ & -1.538 & 1.217 & -1.264 & .208 & & & & & -0.460 & 0.821 & -0.561 & .576 & & & & \\
\hline $\mathrm{X} 3$ & 1.134 & 2.016 & .562 & .574 & & & & & & & & & 0.258 & 1.531 & .169 & .866 \\
\hline X4 & .193 & .038 & 5.086 & .000 & .194 & .037 & 5.269 & .000 & .196 & .037 & 5.248 & .000 & .200 & .035 & 5.672 & .000 \\
\hline X5 & .993 & .408 & 2.433 & .016 & .900 & .380 & 2.366 & .019 & 1.019 & .401 & 2.540 & .012 & .856 & .369 & 2.322 & .021 \\
\hline X6 & -.297 & .368 & -.806 & .421 & -.380 & .340 & -1.118 & .265 & -.307 & .365 & -.840 & .402 & -.470 & .319 & -1.475 & .141 \\
\hline $\mathrm{X} 7$ & -.389 & .523 & -.744 & .457 & -.197 & .501 & -.393 & .694 & -.412 & .509 & -.808 & .420 & -.230 & .478 & -.482 & .630 \\
\hline $\mathrm{X} 8$ & -1.479 & .886 & -1.670 & .096 & -1.568 & .824 & -1.902 & .058 & -1.498 & .870 & -1.721 & .087 & -1.616 & .786 & -2.055 & .041 \\
\hline X9 & -.580 & .485 & -1.195 & .233 & -.479 & .461 & -1.038 & .300 & -.552 & .480 & -1.152 & .251 & -.423 & .440 & -0.961 & .337 \\
\hline $\mathrm{X} 10$ & -.036 & .364 & -.098 & .922 & .001 & .340 & .004 & .997 & -.069 & .358 & -.193 & .847 & -.010 & .326 & -.031 & .976 \\
\hline $\mathrm{X} 11$ & .211 & .466 & .453 & .651 & .325 & .423 & .769 & .442 & .142 & .459 & .308 & .758 & .171 & .397 & .432 & .666 \\
\hline $\mathrm{X} 12$ & -.220 & .561 & -.393 & .695 & -.378 & .521 & -.725 & .469 & -.171 & .549 & -.312 & .755 & -.439 & .501 & -.876 & .382 \\
\hline $\mathrm{X} 13$ & .068 & .911 & .074 & .941 & -.018 & \begin{tabular}{l|l}
.878 \\
\end{tabular} & -.020 & .984 & .123 & .897 & .137 & .891 & -.116 & .802 & -.145 & .885 \\
\hline X14 & 1.334 & .568 & 2.349 & .020 & 1.345 & .533 & 2.522 & .012 & 1.316 & .562 & 2.340 & .020 & 1.385 & .516 & 2.684 & .008 \\
\hline $\mathrm{X} 15$ & .954 & .300 & 3.185 & .002 & .790 & .279 & 2.833 & .005 & .963 & .296 & 3.247 & .001 & .742 & .261 & 2.846 & .005 \\
\hline X16 & -.421 & .211 & -1.995 & .047 & -.323 & .197 & -1.645 & .100 & -.391 & .207 & -1.890 & .060 & -.235 & .187 & -1.259 & .209 \\
\hline X17 & .076 & .213 & .359 & .720 & -.080 & .197 & -.406 & .685 & .036 & .208 & .174 & .862 & -.073 & .186 & -.391 & .696 \\
\hline $\mathrm{R}$ & \multicolumn{4}{|c|}{.475} & \multicolumn{4}{|c|}{.449} & \multicolumn{4}{|c|}{.470} & \multicolumn{4}{|c|}{.449} \\
\hline R Square & \multicolumn{4}{|c|}{.226} & \multicolumn{4}{|c|}{.201} & \multicolumn{4}{|c|}{.221} & \multicolumn{4}{|c|}{.202} \\
\hline Adjusted R Square & \multicolumn{4}{|c|}{.169} & \multicolumn{4}{|c|}{.155} & \multicolumn{4}{|c|}{.172} & \multicolumn{4}{|c|}{.159} \\
\hline R Square Change & \multicolumn{4}{|c|}{.226} & \multicolumn{4}{|c|}{.201} & \multicolumn{4}{|c|}{.221} & \multicolumn{4}{|c|}{.202} \\
\hline F Change & \multicolumn{4}{|c|}{3.949} & \multicolumn{4}{|c|}{4.366} & \multicolumn{4}{|c|}{4.450} & \multicolumn{4}{|c|}{4.702} \\
\hline Sig. F Change & \multicolumn{4}{|c|}{.000} & \multicolumn{4}{|c|}{.000} & \multicolumn{4}{|c|}{.000} & & & 00 & \\
\hline
\end{tabular}

Source: own study. 
Table 2. Correlation matrix (Spearman's correlation coefficients)

\begin{tabular}{|c|c|c|c|c|c|c|c|c|c|c|c|c|c|c|c|c|c|c|}
\hline & $\mathrm{Y}$ & $\mathrm{X} 1$ & $\mathrm{X} 2$ & $\mathrm{X} 3$ & $\mathrm{X} 4$ & $\mathrm{X} 5$ & X6 & $\mathrm{X} 7$ & $\mathrm{X} 8$ & X9 & $\mathrm{X} 10$ & X11 & $\mathrm{X} 12$ & $\mathrm{X} 13$ & X14 & $\mathrm{X} 15$ & X16 & X17 \\
\hline $\mathrm{Y}$ & 1 & .001 & -.039 & .056 & $.436^{* *}$ & $.124^{*}$ & $-.112^{*}$ & $.113^{*}$ & $-.108^{*}$ & -.043 & -.037 & .025 & -.035 & .032 & .088 & $.160^{* *}$ & .014 & .000 \\
\hline $\mathrm{X} 1$ & & 1 & $.717^{* *}$ & $.472^{* *}$ & .043 & $.236^{* *}$ & -.073 & $.184^{* *}$ & -.043 & $.124^{*}$ & -.010 & $-.161^{* *}$ & $.158^{* *}$ & .062 & -.011 & .031 & -.020 & -.085 \\
\hline $\mathrm{X} 2$ & & & 1 & $.430^{* *}$ & .073 & $.237^{* *}$ & -.072 & $.133^{*}$ & .044 & $.128^{*}$ & -.006 & $-.174^{* *}$ & $.163^{* *}$ & .078 & .051 & .058 & -.027 & .081 \\
\hline $\mathrm{X} 3$ & & & & 1 & .054 & $.194^{* *}$ & -.035 & $.115^{*}$ & .064 & .069 & -.081 & $-.141^{* *}$ & $.152^{* *}$ & .051 & .035 & .097 & .059 & -.019 \\
\hline $\mathrm{X} 4$ & & & & & 1 & -.030 & -.080 & -.096 & .079 & -.085 & -.089 & -.026 & -.097 & -.001 & -.044 & .063 & .014 & .030 \\
\hline X5 & & & & & & 1 & -.085 & $.584^{* *}$ & -.080 & .074 & .023 & -.051 & .086 & .050 & .027 & .038 & .008 & .025 \\
\hline $\mathrm{X} 6$ & & & & & & & 1 & -.078 & .002 & .043 & -.038 & .008 & -.043 & -.013 & .008 & -.072 & -.088 & -.031 \\
\hline $\mathrm{X} 7$ & & & & & & & & 1 & -.081 & .035 & -.095 & -.066 & .051 & .028 & .002 & .077 & -.006 & -.019 \\
\hline $\mathrm{X} 8$ & & & & & & & & & 1 & .023 & .035 & -.044 & .068 & -.003 & -.024 & -.014 & .097 & .040 \\
\hline X9 & & & & & & & & & & 1 & .057 & $.221^{* * *}$ & $.349^{* *}$ & $.295^{* *}$ & $.252^{* *}$ & -.017 & -.063 & -.006 \\
\hline $\mathrm{X} 10$ & & & & & & & & & & & 1 & $.146^{* *}$ & $.145^{* *}$ & .054 & .047 & .002 & .023 & -.025 \\
\hline $\mathrm{X} 11$ & & & & & & & & & & & & 1 & $.224^{* *}$ & $.219^{* *}$ & $.169^{* *}$ & .032 & -.050 & -.025 \\
\hline $\mathrm{X} 12$ & & & & & & & & & & & & & 1 & $.291^{* *}$ & $.375^{* *}$ & .021 & -.022 & .002 \\
\hline $\mathrm{X} 13$ & & & & & & & & & & & & & & 1 & $.346^{* *}$ & .046 & .000 & .035 \\
\hline X14 & & & & & & & & & & & & & & & 1 & .071 & .078 & $.114^{*}$ \\
\hline $\mathrm{X} 15$ & & & & & & & & & & & & & & & & 1 & $.143^{* * *}$ & $.181^{* *}$ \\
\hline $\mathrm{X} 16$ & & & & & & & & & & & & & & & & & 1 & $.283^{* *}$ \\
\hline $\mathrm{X} 17$ & & & & & & & & & & & & & & & & & & \\
\hline
\end{tabular}

Note: ** correlation is significant at the 0.01 level (2-tailed); * correlation is significant at the 0.05 level (2-tailed).

Source: own study. 


\section{Empirical results, conclusions and limitations}

The estimation for the model with combined variables (Table 1) shows similar results. Our first hypothesis is that the length of relationship banking is higher with older firms. We see a positive relation between the two aspects (length of relationship banking and age of the firm [X4]; Spearman $=0.436, p=0.01$ ). The hypothesis should be accepted. This situation describes the reality well: older firms have a wellestablished and organised financial management, and the relevant persons in the bank(s) and the firm (CFO) know each other over a long time. The bank knows the specifications of the firm well and their financial policy, so it offers tailored products; Sauter [2015, p. 31] came to the same conclusion. The CFO saves time and is satisfied. Both parties are learning over the years and strengthen their relationship.

Therefore, for the banks it is important to look for good personal contacts between their loan specialists and the representatives of the firms and they shall not change their employees too often. This is a valuable aspect especially in the case of mergers.

Hypothesis 2 deals with the number of banks and the contacts between banks and firms. Only the aspect of number of banks collaborating with the firm [X5] is significant; this means that the length of relationship banking is increasing with the number of banks (Spearman $=0.124, p=0.05$ ); this result is in line with von Rheinbaben and Ruckes [2004, p. 1611]. Hypothesis 2 can be only confirmed in this aspect. In general, we can say that Polish firms are collaborating with a low number of banks (1-6) and this amount is lower than in other European countries [Gajewski et al. 2012].

We think that there are some reasons possible to explain this result. One point has the focus on the firm: in the last decades, Poland has had high growth rates and the firms expanded their activities and needed, therefore, more banks, they would perhaps start with a more regionally-oriented bank and needed additional bank with more international experience. A high value of independence may be the reason to look for another bank. A second focus lies on the banks: the competition in the Polish bank market had become more intensive, so it is natural that the number of banks for the firms increased.

The third hypothesis deals with the industry (trade/service vs. manufacturing). We use the value 1 for a manufacturing firm and 0 for firms in the trade and services sector [X8]. The significant negative parameter shows that relationship banking is more intensive if the firm is in the trade and services sector (Spearman $=-0.108$, $p=0.05)$. The trade and services sector in a large country like Poland is more nationally oriented and, therefore, it does not need more banks for complicated problems, it uses its long-term bank structure with good experience.

When analysing Hypothesis 4: the length of relationship banking depends on the strategies and goals of the firm; we looked at six goals and strategies [X9-X14]. We were only able to accept variable X14 (i.e. minimizing enterprise risk - Spearman not significant). Firms which are more oriented at reducing the risk of the firm are more 
focused on relationship banking. This is a clear picture, because - as we mentioned above - relationship banking is a kind of insurance against the crisis. We can only accept the hypothesis partially.

In Hypothesis 5 we test the influence of a good access to bank loans [X15]. And it is reality that when the firms say that they have a good access to loans (in 2013) the length of relationship banking is higher (Spearman $=0.160, p=0.05$ ). We think this shows the value of relationship banking: the level of information about the firm in the bank is high, the parties know each other and so the impression in the firm is that it has a good access to loans.

Our last hypothesis deals with the contentment with short- and long-term bank loans [X16, X17]. Only the contentment with the short-term bank loans is in a negative relation significant (Spearman not significant), this means that a high contentment with short-term loans leads to stop relationship banking, maybe the impression is that the conditions are better for the firm under full competition.

We summarize that the length of relationship banking is higher with older firms, with firms which want to reduce their risks, depends on the number of banks and is higher by good access to loans. Relationship banking is more important in the sector of trade and services.

There are some limitations of this contribution to research. We have data from a relatively high number of Polish firms, but they cannot be a whole picture of the real world in size, industry, etc. It would be interesting to compare the results with other countries, to explain if there are some cultural influences.

\section{References}

Berger A.N., Udell G.F., 1995, Relationship Lending and Lines of Credit in Small Firm Finance, Journal of Business, vol. 68, p. 350-381.

Berger A.N., Udell, G.F., 2002, Small business Credit Availability and Relationship Lending, The Importance of Bank Organisational Structure, The Economic Journal, vol. 112, p. F32-F53.

Bharath S., et al., 2007, So what do I get? The bank's view of lending relationships, Journal of Financial Economics, vol. 85, p. 368-419.

Carletti E., 2004, The structure of bank relationships, endogenous monitoring, and loan rates, Journal of Financial Intermediation, vol. 13, p. 58-86.

Degryse H., Van Cayseele P., 2000, Relationship Lending within a Bank-Based System: Evidence from European Small Business Data, Journal of Financial Intermediation, vol. 9, p. 90-109.

Elsas R., 2005, Empirical determinants of relationship lending, Journal of Financial Intermediation, vol. 14 , p. 32-57.

Elyasiani E., Goldberg L.G., 2004, Relationship lending: a survey of literature, Journal of Economics and Business, vol. 56, p. 315-330.

Gajewski K., Pawłowska M., Rogowski W., 2012, Relacje firm z bankami w Polsce w świetle danych ze sprawozdawczości bankowej, Materiały i Studia, no. 275.

Iturralde T., Maseda A., San-Jose L., 2010, Empirical Evidence of banking relationships for Spanish SMEs, International Small Business Journal, vol. 28, p. 274-295. 
Pernsteiner H., Węcławski J., 2016, How do Polish non-listed family firms engage in strong relationship banking?, Contemporary Problems in Corporate Governance, no. 2016/3, p. 45-57.

v. Rheinbaben H., Ruckes M., 2004, The number and the closeness of bank relationships, Journal of Banking and Finance, vol. 28, p. 1597-1615.

Sauter K., 2015, Die Hausbankenbeziehung aus Sicht von Familienunternehmen, Bank und Markt, no. 6, p. $28-31$.

Tymoczko I.D., 2012, Charakter wspólpracy przedsiębiorstwa z bankiem a warunki cenowe kredytu bankowego, Materiały i Studia, no. 268. 